DOI: doi.org/10.21009/IJLECR.062.15

Received: 12 May 2020

Revised: 15 June 2020

Accepted: 5 November 2020

Published: 1 December 2020

\title{
INTEGRATING 21ST CENTURY "COMMUNICATION \& COLLABORATION" SKILLS INTO FRENCH LISTENING COMPREHENSION COURSE BY UTILIZING YOUTUBE CHANNEL
}

\author{
Ratna $^{1, a)}$ \\ Universitas Negeri Jakarta ${ }^{1)}$ \\ ratna@unj.ac.ic ${ }^{a)}$
}

\begin{abstract}
The purpose of this study is to create a lesson plan as a supplement for Réception Orale I course that is integrated with 21st century skills and based on Youtube Channel. This design is created as an effort to employ the information technology in the course, which by far is deemed to be unable to merge the blended learning on its maximum effort. The importance of this Blended Learningbased research is conducted to improve students' listening skills in French Language Study Program (FLSP) through audio-visual learning media that is in line with technological developments, namely the Youtube Channel. Youtube Channel which will be used as a learning medium in listening comprehension course in FLSP is a special channel that is identified based on the suitability of the material in the Course Design (RPS) of the listening comprehension. The design of the Youtube Channel will set off by uploading videos that are relevant to the learning needs of listening skills so that learning objectives can be achieved. The result of this study is the supplement design for French listening comprehension course which is based on Youtube Channel. The finding of this paper may shed the light in paving our way to prepare ourselves to face Industrial Revolution 4.0, which characteristics among others is the use of information technology in the learning process.
\end{abstract}

Keywords: $21^{\text {st }}$ century, listening comprehension, blended learning, Youtube channel

As we face the Information and Communication Technology (ICT) era which is the basis of the 4.0 industrial revolution certainly affects the improvement on the quality of learning in educational institutions. University as the highest educational institution should properly use ICT to improve the quality of learning, so that it produces graduates who are able to apply 21 st century skills. This should be done because learning activities are the most basic activities in the educational process therefore will be impacted upon the quality education.

As general convention, that information technology develops in line with the development of communication theories and technologies that support the practice of learning activities. Computer-based learning, Web-based (e-learning), and Audio Visual Aids-based (AVA) are samples how educational technologies employed must have ongoing development. These technologies will also be directed towards achieving 21st century skills which include Communication, Collaboration, Critical Thinking and Problem Solving, and Creativity and Innovation. Thus, for the achievement of educational goals, the learning process should be designed based on ICT so that graduates are ready to face 21 st century challenges such as globalization, international competition, technology, environment, and international politics. 
It is so crystal clear that within the boundary of education, IR 4.0 is so massively required. Universities have a big responsibility in creating graduates who are ready for the digital age. For this reason, lecturers are considered as the quality guarantor of higher education dynamic element who is the foremost actors in the 21 st century learning process. This leads to a truth that, the quality of learning process is the result of good learning plan for achieving 21st century skills for graduates.

Setting off from this situation, lecturers must be able to think critically and innovatively towards the use of information technology in classroom learning, and be able to direct themselves in following the development of information technology that has an impact on learning media as foreign language instructor. Therefore, a foreign language instructor will be able to be adaptive and have initiative in making learning media suitable with the learning needs and objectives (Meskill, 1996).

Related to foreign language learning that is in this case is French in FLSP curriculum, there are four language skills that must be mastered by the learner, namely speaking, listening, reading skill and writing. The four skills are given in an integrated way during the first two years of learning (from the $1^{\text {st }}$ semester to $4^{\text {th }}$ semester). It aims to strengthen students' language competences in FLSP that lead to the achievement of the vision and mission of the FLSP: to produce French scholars who are able to communicate in French either oral or written equivalent to DELF B2 (French Degree).

However, it should be underlined that the language skills achieved in the first two years are at A2 level. Then to achieve B2 level, students will take advanced language skills courses in the third and fourth years, namely Maîtrise de Langue I, II, and III courses. So that practically and theoretically it can be said that the four language skills in the first two years become the main basic that must be strengthened to take the language skills at an advanced level in order to achieve B2 level of French language skills. Of course, as previously explained that currently learning in universities must be in line with the industrial revolution 4.0 so that the use of ICT in learning cannot be ignored. Likewise, graduates should also possess the 21 st century skills to enable them to compete in the era of globalization.

Listening skills basically include two processes at once, namely processes and actions, as Ferroukhi said: la comprehension orale: un processus et un comportement »qui nous permets de décrire ce processus selon deux modèles différents. Dans l'un, la construction du sens d'un message est envisagée comme une démarche sémasiologique (de la forme au sens), dans l'autre, elle est envisagée comme une démarche onomasiologique (du sens à la forme) Modèle sémasiologique: de laaute la forme au sens (ascendant) (Ferroukhi, 2009). From the statement explained, that the listening process includes the process of constructing the meaning of the message delivered, known as the semasiology stage (from form to meaning) and the process of constructing meaning to form is known as the onomasiology stage. Both processes will become learners' experiences during the listening skills lesson.

In relation to how to increase the understanding of listening to foreign language learners, of course this is not easy, but it requires explicit and systematic teaching outside of vocabulary, such as syntactic structure, conclusions, thoughts and emotions of characters, and monitoring of understanding (Kim \& Pilcher, 2016). Meanwhile in learning activities, students should be required to describe the oral text that is heard into the spoken language by expressing their feelings and attitudes related to the topic of the oral text so that learner can extract meaning of the oral text.

Simultaneously, integrating 21st century skills in learning listening skills certainly requires the right strategy so that learning objectives can be achieved. The National Education Association (n.d.) has identified 21st century skills as "The 4Cs" skills. "The 4Cs" include Critical Thinking and Problem Solving, Creativity and Innovation Communication, Collaboration. Critical thinking skills are skills to carry out various analyzes, assessments, evaluations, reconstruction, decision making 
that lead to rational and logical actions (King, et al., 2010). Thinking activities regarding subjects, contents, and problems are carried out through analysis, assessment, and reconstruction activities (Papp, et al., 2014). Creativity is a skill to discover new things that have never existed before, is original, develops various new solutions for each problem, and involves the ability to generate new, varied, and unique ideas (Leen, et al., 2014). Communication skills are skills to express thoughts, ideas, knowledge, or new information, both written and oral. Collaborative skills are skills that work together effectively and show respect for diverse team members, practicing fluency and willingness to make the decisions needed to achieve common goals (Greenstein, 2012).

Responding to the demands of 21 st century skills, of course listening skills today are not just the process of hearing verbal symbols or the sounds of language but listening requires complex activities as a basis for acquisition and learning. Therefore, information technology especially that emphasizes the visual aspects can be improved to achieve more effective language skills (Meskill, 1996). A similar sentiment was also said by (Ginther A, 2002) and (Ockey, n.d.) that the visual aspects of images and videos can improve the listening comprehension test. According to them, listening is not only complex understanding of the spoken utterances expressed by the speaker, but the visual element is also embraced in listening skill activities. This problem has finally become the attention of researchers to be able to develop innovative listening skills learning through information technology and integrated with 21 st century skills.

Responding to the situation, then as an educator it would be good to address these problems by taking appropriate steps and in accordance with the problems encountered. Of course, this is related to the learning model that must be adapted to the needs and learning objectives. The blended learning model can certainly be a solution in improving listening learning outcomes. But blended learning in this research still prioritizes face-to-face lectures by utilizing information technology in the form of audio-visual media Youtube channel where the instructor remains as the main learning source. The instructor conveys learning content, conducts questions and answers, discussions, gives guidance, assignments, and exams.

Youtube Channel as a learning platform that is now well-known is one of the most popular media to promote the field that is being created to attract attention. Youtube Channel can be a source of learning and learning media that can meet the needs of entertainment, learning, data search, and others. The digital generation with its many conveniences utilizes Youtube Channel to get learning resources. Learners also use Youtube Channel to upload lecture material so that it is easily accessible to all learners and share knowledge.

Youtube Channel which will be used as a learning media in the Listening Skills I in FLSP is a special channel that is identified based on the suitability of the material in course design of the Listening Skills I. The design of the Youtube channel will be set out by uploading a video relevant to the learning needs of listening skills so that learning objectives can be achieved. The designedYoutube channel will contain various themes according to the needs and identification of problems/obstacles encountered by the instructor while attending the Listening Skills course.

Various studies related to the integration of 21st century skills in language learning have been carried out including research conducted by (Albahlal, 2019). A study aimed at exploring 21st century skills and how these skills can be integrated into English learning. The results of this study present a series of steps or strategies for integrating 21st century skills into English learning. Albahlal also described the things such as the importance of increasing teacher awareness about 21 st century skills, the importance of these skills and the need for various training for teachers to practice these skills in their classrooms. The same research was also carried out in Turkey, which aims to integrate 4C's skills in learning English as a foreign language (EFL) (Erdogan, 2019). In his research, Erdogan emphasized the importance of 4C's skills as a form to correspond with the development of technology in the global workforce. $4 \mathrm{C}$ skills and innovation must be incorporated 
into the language teaching and learning process with an emphasis on improving and promoting students' life skills. The results of this study provide a variety of recommendations for teachers to create creative ways so that students can respond to the 21 st century.

On the other hand, a very interesting study was also conducted to see the extent to which teachers are open to innovation and the extent to which innovative digital methods for teaching foreign languages affect teacher performance (Karsenti \& Kozarenko, 2019). In their paper, they explained various challenges in providing pedagogical support for innovative initiatives in foreign language classes. The results of this study take the form of 25 practical recommendations for applying a digital approach to language classes. The aim is to help foreign language teachers work with digital methods and tools more efficiently and effectively. Karsenti and Kozarenko's research at least refers to blended learning-based learning as one form of the 4.0 industrial revolution which boils down to 21 st century skills. Other previous study deals with improving students' speaking ability using Mobile Assisted Language Learning (MALL) learning model (Hadi \& Emzir, 2016). The aim of this study is to reveals in details process and result of improving English speaking ability using Mobile assisted Language Learning (MALL) model. This study is an action research at English Department Muhammdiyah University of Jakarta, consists of 30 students as the participant. Data is obtained from the result of English-Speaking ability test. The results of the study showed that the learning process using Mobile Assisted Language Learning (MALL) makes the students become more active in their speech; their participation level in learning interaction shows it.

Based on this background, it is necessary to conduct research on the use of Youtube Channel as a source of learning/media for students' learning. The technical reason that makes this research important to do is that the Youtube channel can anticipate the minimum conditions of facilities and infrastructure in this case is Wireless Fidelity (Wi-Fi), this hinders access to internet in particular in the classroom (on-off) context. While the pedagogical reason is that the Youtube channel can be an audio-visual medium that can support the listening activities of listening skills in a foreign language, which at the same time involves the process of hearing and seeing to capture verbal and nonverbal messages from the video being displayed. For that reason, the problem in this research is how to integrate 21st century skills in the listening skills (Réception Orale I) course employing Youtube channel as a learning media in FLSP. The 21st century skills that will be integrated in this study are limited to Communication and Collaboration, because they are adapted to the scope of listening skill course (A1 level) based on the Cadre Européen Commun de Référence pour les Langues (CECR).

\section{METHOD}

In this research, the writer used design of descriptive method, a method of research that attempt to describe and interpret the objects in accordance with reality. The descriptive method is implemented because the data analysis is presented descriptively. Moreover, (Sugiyono., 2012) gives the important features of qualitative research in investigating the literature, such as the researcher is the key of instrument that reads the literature thrifty, the research is done descriptively which elaborated in the form of words or pictures than numbers and the process is more priority than result because literature establishes interpretations.

The source of data in this study is course design of listening skill (RPS) which serves as a teacher's reference for carrying out learning in class for one semester. Referring to the existing course design, a supplement to course design for listening skill was developed. This supplement design aims to complement the needs of teaching materials of listening skill, which are considered to have not optimally utilized information technology as part of the practice for blended learning. In this study, the themes developed are limited to only four themes contained in the course design of listening skill, they are introducing family (présenter la famille d'autrui et sa famille), expression of 
time (expression de l'heure), daily activities (activités quotidiennes), and telling activities to be carried out in the future.

\section{RESULTS AND DISCUSSION}

The use of Youtube channel can certainly be a solution in improving listening learning outcomes. Blended learning-based learning model in this research still prioritizes face-to-face lectures by utilizing information technology in the form of audio-visual media Youtube channel where the instructor remains as the main learning source. The instructor conveys learning content, conducts questions and answers, discussions, gives guidance, assignments, and exams. The learning model applied in this companion learning design will focus on student-centered. In this case, the main task of students is to find a video conversation in Youtube channel which must be related to learning topics. Of course, there are requirements that must be considered by students regarding the selection of video conversations. The requirements in question are the criteria for selecting the video from Youtube should be in accordance with themes. These themes will be presented on below table as data in this study: introducing family (présenter la famille d'autrui et sa famille), expression of time (expression de l'heure), daily activities (Activités quotidiennes), and telling activities to be carried out in the future (Parler des activités d'avenir).

\section{Result}

Lesson Plan of French Listening Skill I by using Youtube Chanel

\begin{tabular}{|c|c|c|c|c|}
\hline No & Topic & Indicator & $\begin{array}{c}\text { Youtube } \\
\text { Chanel's criteria }\end{array}$ & Learning activities \\
\hline 1 & $\begin{array}{l}\text { Introducing } \\
\text { family } \\
\text { (présenter la } \\
\text { famille } \\
\text { d'autrui et sa } \\
\text { famille). }\end{array}$ & $\begin{array}{l}\text { 1. Identifying } \\
\text { names related to } \\
\text { family } \\
\text { relationships } \\
\text { (père, mère, } \\
\text { soeur, frère, etc.) } \\
\text { 2. Using expression } \\
\text { to introduce } \\
\text { family, for } \\
\text { example: C'est } \\
\text { mon père. Il } \\
\text { s'appelle Vincent. } \\
\text { Et voilà ma mère, } \\
\text { Sylvie. Ils ont } 2 \\
\text { enfants: } \\
\text { Jonathan, mon } \\
\text { frère et moi, } \\
\text { Cloé, etc. }\end{array}$ & $\begin{array}{l}\text { Youtube chanel } \\
\text { that contains the } \\
\text { topics about } \\
\text { introducing } \\
\text { family. }\end{array}$ & $\begin{array}{l}\text { 1. The teacher shows a } \\
\text { Youtube channel that } \\
\text { contains topics about } \\
\text { family. } \\
\text { 2. The teacher distributes } \\
\text { worksheets that will be } \\
\text { done in groups ( } 2 \\
\text { studens). } \\
\text { 3. The teacher asks the } \\
\text { group to identify the } \\
\text { name / family } \\
\text { relationship, age, etc. } \\
\text { 4. The teacher and students } \\
\text { correct together the } \\
\text { completed tasks. } \\
\text { 5. The teacher asks students } \\
\text { to tell their families } \\
\text { verbally. } \\
\text { 6. The teacher records the } \\
\text { wrong utterances and } \\
\text { expressions. } \\
\text { 7. The teacher explains the } \\
\text { mistakes and fixes them. }\end{array}$ \\
\hline 2 & $\begin{array}{l}\text { Expression of } \\
\text { time } \\
\text { (expression de }\end{array}$ & $\begin{array}{l}\text { 1. Using Expression of } \\
\text { time, Ex: il est une } \\
\text { heurel il st deux }\end{array}$ & $\begin{array}{l}\text { 1. Youtube } \\
\text { Chanel that } \\
\text { contains }\end{array}$ & $\begin{array}{l}\text { 1. The teacher shows a } \\
\text { Youtube channel which } \\
\text { contains expression of }\end{array}$ \\
\hline
\end{tabular}




\begin{tabular}{|c|c|c|c|c|}
\hline No & Topic & Indicator & $\begin{array}{c}\text { Youtube } \\
\text { Chanel's criteria }\end{array}$ & Learning activities \\
\hline & l'heure). & $\begin{array}{l}\text { heures/ il est deux } \\
\text { heures dix, quinze/ } i \\
\text { lest deux heurs et } \\
\text { demie, etc. } \\
\text { 2. Using expression of } \\
\text { time to ask and } \\
\text { answer the } \\
\text { question, Ex: } \\
\text { Quelle heure est- } \\
\text { il?/Il est quelle } \\
\text { heure?/ Vous avez } \\
\text { l'heure, s'il vous } \\
\text { plaît/ tu as l'heure, } \\
\text { s'il vous plaît? } \\
\text { La pharmacie } \\
\text { ouvrel ferme à } \\
\text { quelle heure? } \\
\text { Elle fermel ouvre à }\end{array}$ & $\begin{array}{l}\text { Expression of } \\
\text { time. } \\
\text { 2. Writing the } \\
\text { Youtube } \\
\text { chanel's } \\
\text { address }\end{array}$ & $\begin{array}{l}\text { time } \\
\text { 2. The teacher gives } \\
\text { worksheets and asks } \\
\text { students to write down the } \\
\text { time specified, for } \\
\text { example il est huit heures. } \\
\text { 3. The teacher writes on the } \\
\text { board operational time } \\
\text { "open and closed" for } \\
\text { offices, shops, theaters } \\
\text { and then asks students to } \\
\text { pair up to conduct mini } \\
\text { dialog. Example: - } \\
\text { Bonjour madame / } \\
\text { monsieur la poste ouvre à } \\
\text { quelle heure? Et elle } \\
\text { ferme à quelle heure? - } \\
\text { Elle ouvre à ... et ferme à } \\
\text {... }\end{array}$ \\
\hline 3 & $\begin{array}{l}\text { Daily activities } \\
\text { (Activités } \\
\text { quotidiennes). }\end{array}$ & $\begin{array}{l}\text { 1. Identifying } \\
\text { expression for } \\
\text { describing daily } \\
\text { activities: the use of } \\
\text { pronominal verbs. } \\
\text { Example: Je me } \\
\text { lève, je me douche, } \\
\text { je m'habille etc. } \\
\text { 2. Telling daily } \\
\text { activities by using } \\
\text { logical connector. } \\
\text { Example: d'abord, } \\
\text { et puis, ensuite et } \\
\text { enfin. }\end{array}$ & $\begin{array}{l}\text { 1. Youtube } \\
\text { channel } \\
\text { which tells } \\
\text { about daily } \\
\text { activities. } \\
\text { 2. Writing the } \\
\text { Youtube } \\
\text { channel's } \\
\text { adresse used. }\end{array}$ & $\begin{array}{l}\text { 1. The teacher shows } \\
\text { Youtube channel selected } \\
\text { by students. } \\
\text { 2. The teacher distributes } \\
\text { assignment sheets that } \\
\text { must be filled out by } \\
\text { students by choosing true } \\
\text { or false answers. They } \\
\text { were then asked to correct } \\
\text { it if it was wrong. } \\
\text { 3. The teacher asks students } \\
\text { to have a session } \\
\text { question-answer with } \\
\text { their friends about daily } \\
\text { activities Example: } A 5 \\
\text { heures, qu'est-ce que tu } \\
\text { fais? - A } 5 \text { heures, je me } \\
\text { lève, etc. } \\
\text { 4. The teacher records } \\
\text { errors, expressions, } \\
\text { utterances and grammar } \\
\text { then explain them in such } \\
\text { that students can } \\
\text { understand. } \\
\text { 5. The teacher asks students } \\
\text { to write the activities of }\end{array}$ \\
\hline
\end{tabular}




\begin{tabular}{|c|c|c|c|c|}
\hline No & Topic & Indicator & $\begin{array}{c}\text { Youtube } \\
\text { Chanel's criteria }\end{array}$ & Learning activities \\
\hline & & & & an important person. \\
\hline 4 & $\begin{array}{l}\text { Telling the } \\
\text { activities that } \\
\text { will be carried } \\
\text { out in the } \\
\text { future (Parler } \\
\text { des activités } \\
\text { d'avenir) }\end{array}$ & $\begin{array}{l}\text { 1. Identifying } \\
\text { expression for } \\
\text { describing future } \\
\text { activities (verb } \\
\text { aller + infinitive). } \\
\text { 2. Telling orally } \\
\text { activities carried } \\
\text { out in the future }\end{array}$ & $\begin{array}{l}\text { 1. Youtube } \\
\text { channel } \\
\text { contains } \\
\text { expression to } \\
\text { tell upcoming } \\
\text { activities } \\
\text { 2. Youtube } \\
\text { channel } \\
\text { address is } \\
\text { written in the } \\
\text { answer sheet. }\end{array}$ & $\begin{array}{l}\text { 1. The teacher asks students } \\
\text { to present their chosen } \\
\text { Youtube channel } \\
\text { according to the learning } \\
\text { topic. } \\
\text { 2. After watching together, } \\
\text { the teacher asks the } \\
\text { student to explain the } \\
\text { activities that will be } \\
\text { carried out by a character } \\
\text { on the Youtube channel. } \\
\text { 3. The teacher asks other } \\
\text { students to write on the } \\
\text { verb board used (Aller }+ \\
\text { infinitive). } \\
\text { 4. The teacher asks students } \\
\text { to use the activity with } \\
\text { other pronouns, such as je } \\
\text { / tu / vous, nous, etc. } \\
\text { 5. The teacher asks students } \\
\text { to talk about the activities } \\
\text { that will be done in the } \\
\text { future (holiday's } \\
\text { planning, next week } \\
\text { planning etc.). } \\
\text { 6. The teacher records the } \\
\text { mistakes made by the } \\
\text { learner. } \\
\text { 7. The teacher explains the } \\
\text { mistakes and recalls the } \\
\text { phrase that was just being } \\
\text { learned. } \\
\text { 8. The teacher asks the } \\
\text { learner to write an activity } \\
\text { that will be done by } \\
\text { someone important, or } \\
\text { someone who is famous } \\
\text { (célébrité) }\end{array}$ \\
\hline
\end{tabular}

\section{Discussion}

Introducing family (présenter la famille d'autrui et sa famille).

Setting off from those videos uploaded on the Youtube Channel that have been uploaded by students, the teacher shows Youtube channels that contain themes about family. After that, the 
teacher distributes worksheets that will be done in groups ( 2 people). The teacher asks the group to identify names, family relationships, ages and so on according to the information contained in the video. Then, the teacher and student come together to correct the completed task. The teacher asks students to tell verbally about his family. At the same time, the teacher records the utterances and phrases that are incorrect. After that the teacher gives the opportunity to other groups to correct the mistakes of the groups in charge before the teacher gives input or conclusions on the theme of the lesson.

\section{Expression of time (expression de l'heure)}

From the Youtube Channel that has been uploaded by students, students show Youtube channels that contains expression of time. This theme is previously discussed in the aforementioned table. Before showing and playing the video, the teacher gives a group worksheet and asks each group to write down the time specified, for example il est huit heures. The teacher then writes on the board about operational hours of "open and close" offices, shops, theatres, and so on. Then ask students in pairs to conduct a mini dialogue. Example: Bonjour madame / monsieur la poste ouvre à quelle heure? Et elle ferme à quelle heure? - Elle ouvre à ... et ferme à ... Pronunciation can be corrected through peers or indirectly by the teacher herself.

\section{Daily activities (Activités quotidiennes)}

The teacher shows the Youtube channel chosen by the students. The teacher distributes group work sheets that must be filled out by students by choosing true and false answers. Then they were asked to correct it if their answers were wrong. The instructor asks students to conduct inter-group questions about daily activities, for example: A 5 heures, qu'est-ce que tu fais? - A 5 heures, je me leve, etc. The teacher records errors, expressions, pronunciation, and grammar then explains them. In term of evaluation, teacher ask students to write someone's activities they admire, they can be their father or mother, or famous people such as singers, movie stars and so on. With this activity students will certainly try to express their ideas and to communicate to their classmates.

\section{Telling the activities that will be carried out in the future (Parler des activités d'avenir)}

The instructor asks students to present their chosen Youtube channel in accordance with the learning topic. After watching together, teachers asked students to explain the activities to be carried out by the person in the channel Youtube. The teacher asks other students to write on the board the verb used (Aller + infinitive). At the same time, each student was asked to make a sentence with this formulation, for example conveying "What will you do after graduating from college?"

In term of oral evaluation final stage, teacher asks students to tell verbally activities that will be carried out in the future (vacation plans, activities that will be done on weekends, etc). The students finally give feedback to each other, so learning activities lead to actions and reactions. The teacher not only records errors made by students but also allows them to correct mistakes made by their friends until finally the students explain the errors and recall the expressions being studied as the written evaluations, then students ask the learner to tell in writing the activities to be carried out by someone he admires or a famous person ( célébrité).

\section{1st Century skills « communication and collaboration » in listening skill's activities}

Setting off from the learning design described in each learning theme, it can be explicitly stated that 21 st century skills, which in this study are limited to communication and collaboration 
skills, have been reflected in learning activities. Group work on every activity especially when they are looking for and uploading videos from Youtube Channel already reflects collaboration among peers. Even more, when they are together deciding whether the chosen Youtube Channel matches the indicators requested by the instructor. Collaborative skills in this context also mark a joint decision to agree on a Youtube Channel that will be used as a learning medium. This is consistent with the characteristics of collaboration skills, namely working together effectively and showing respect to diverse team members, practicing togetherness in making the decisions needed to achieve common goals. This situation certainly reflects an active and conducive class. This is consistent with what Albahlal (2019) said that activities such as, not only encourages the development of speaking and listening skills, but also teaches students how to effectively achieve a common goal.

The activity of giving each other feedback also greatly reflects communication skills, because in this activity, students try to provide thoughts, ideas as well as new information for their colleagues related to the theme being studied. Moreover, the question and answer activities of Youtube Channel showed a pattern of communication between students, this was due to the different variations of the Youtube Channel they found. With this question and answer activities, students will create actions and reactions in the class. The actions and reactions of fellow students certainly illustrate the existence of intense communication during the learning process in class. Teachers are facilitators will bridge the things that they cannot solve together in this case. Thus, reflected a student-centered learning model as a form of 21 st century learning.

In principle, ICT applications strengthen and enhance the possibility of communication and strengthen the development of coordination and collaboration skills between friends. For this reason, students as the young generation need to have the ability to communicate, exchange ideas, criticize, and present information and ideas through the use of ICT applications. At least the use of ICT applications such as Youtube Chanel in the class will make them adaptive to digital culture. The application of digital culture to language classes will leave them with communication skills that originate from authentic/real life situations. This according to Erdogan (2019) will make it possible for students to communicate with students from other communities; this is an obvious demand in 21 st century learning.

\section{CONCLUSION}

The use of Youtube Channel as a learning medium makes teaching and learning activities in the classroom become increasingly diverse and interesting for students. In particular when applied in Listening course, this media is expected to be able to make learning the listening skills which was initially considered as the most difficult becomes easier to learn. This media also accommodates the needs of students' learning styles, both visual, auditory, and kinaesthetic and make those easy for them to capture the verbal and nonverbal messages contained in the video. In addition, this media is used as an effort to utilize technology and the application of blended learning, given the continued development of technology. This effort not only aims to vary the learning media, but also makes it easier for students to understand the material being discussed because it is clearer and more illustrated the situation. In addition, French is a foreign language which is quite far from the lives of Indonesian students, so it requires various teaching media, such as Youtube Channel. By creating a supplement design which is integrated with 21 st Century skills and based on Youtube Channel, the learning will enable students to become autonomous learners or autonomous learning because the learners themselves will explore teaching materials through the Youtube Channel.

\section{REFERENCES}

Albahlal, F. S. (2019). The Integration of 21th Century Skills into English Language Learning. Journal of Applied Linguistics and Language Research, 6(3), 144-154. 
Erdogan, V. (2019). Integrating 4C Skills of 21st Century into 4 Language Skills in EFL Classes Vacide Erdoğan. International Journal of Education and Research, 7(11), 113-124. Retrieved from www.ijern.com

Ferroukhi, K. (2009). La compréhension orale et les stratégies d' écoute des élèves apprenant le français en 2 ème année moyenne en Algérie. Synergies Algérie, 4, 273-280. Retrieved from http://gerflint.fr/Base/Algerie4/ferroukhi.pdf

Ginther A. (2002). Context and Content Visual and Peformance on Listening Comprehension Stimuli. Language Testing, 19(2), 133-167.

Greenstein, L. (2012). Greenstein, L., 2012, Assessing 21st Century Skills: A Guide to Evaluating Mastery and Authentic Learning. California: California: Corwin.

Hadi, M. S., \& Emzir, E. (2016). Improving English Speaking Ability through Mobile Assisted Language Learning (Mall) Learning Model. Ijlecr - International Journal of Language Education and Culture Review, 2(2), 71-74. https://doi.org/10.21009/ijlecr.022.09

Karsenti, T., \& Kozarenko, O. M. (2019). New technology trends and innovative teaching of foreign languages: What are the most effective teaching strategies? XLinguae, 12(1XL), 128144. https://doi.org/10.18355/XL.2019.12.01XL.10

Kim, Y.-S. G., \& Pilcher, H. (2016). What Is Listening Comprehension and What Does It Take to Improve Listening Comprehension? Literacy Studies 13, DOI 10.1007/978-3-319-31235-4_10, 13. https://doi.org/DOI 10.1007/978-3-319-31235-4_10

Meskill, C. (1996). Listening Skills Development Through Multimedia. Journal of Educational Multimedia and Hypermedia, 5(2), 179-201.

Ockey, G. J. (n.d.). Construct Implications of Including Still Image or Video in Computer Based Listening Test. Language Testing, 24(4), 517-537.

Sugiyono. (2012). Memahami Penelitian Kualitatif. Bandung: Alfabeta. 